\title{
PENERAPAN TEKNIK SCAFFOLDING SEBAGAI UPAYA MENINGKATKAN KEMANDIRIAN BELAJAR ANAK USIA 5-6 TAHUN DI TK KRISTEN KADASITURU TERPADU
}

\author{
Eny Suprihatin \\ Sekolah Tinggi Agama Kristen Terpadu-PESAT \\ email: prihatineny67@yahoo.co.id \\ Dan \\ Desti Rosita \\ Sekolah Tinggi Agama Kristen Terpadu-PESAT \\ email: rositaechidesti1@gmail.com
}

\begin{abstract}
ABSTRAKSI
Kemandirian adalah sikap hidup yang diperlukan untuk kemajuan sebuah bangsa. Manusia mandiri mampu dengan dewasa menghadapi tantangan zaman. Kemandirian tidak dapat terjadi secara instan, perlu dibiasakan. Waktu yang tepat untuk pembiasaan adalah usia dini. Penelitian tentang penerapan teknik pembelajaran Scaffolding sebagai upaya meningkatkan kemandirian belajar anak usia 5-6 tahun, menggunakan metodologi Penelitian Tindakan Kelas dilakukan di TK Kristen Kadasituru Terpadu. Model PTK yang digunakan adalah model Kurt Lewin. Empat tahapan yang dijalankan: perencanaan, pelaksanaan, pengamatan dan refleksi. Hasilnya adalah terjadi peningkatan yang signifikan terhadap peningkatan kemandirian belajar anak. Observasi awal tingkat kemandirian 17 subjek penelitian skor rata-rata adalah 6,61\% masuk kategori Belum Berkembang (BB). Setelah dikenakan tindakan dalam empat siklus, kemandirian belajar anak naik signifikan skor rata-rata 98,52\% memenuhi kriteria Berkembang Sangat Baik (BSB).
\end{abstract}

\section{Kata kunci: Kemandirian belajar, Scaffolding, usia dini}

\begin{abstract}
Independence is the attitude of life needed for the progress of a nation. An independent human being is able to mature to face the challenges of the times. Independence cannot happen instantly, it needs to be familiarized. The right time for habituation is early age. Research on the application of Scaffolding learning techniques as an effort to increase the learning independence of children aged 5-6 years, using the Classroom Action Research methodology conducted at Kadasituru Integrated Christian Kindergarten. The research model used is the Kurt Lewin model. Four stages are carried out: planning, implementing, observing and reflecting. The result is a significant increase in the improvement of children's learning independence.Initial observation of the level of independence of 17 research subjects the average score was $6.61 \%$ in the category of Not Developing (BB). After taking action in four cycles, children's learning independence significantly increased the average score of $98.52 \%$ to meet the criteria of Very Good Development (BSB).
\end{abstract}

Keywords: Learning independence, Scaffolding, early age 


\section{PENDAHULUAN}

Kemajuan sebuah bangsa ditentukan oleh kualitas sumber daya manusianya. Manusia yang mandiri dalam semua aspek kehidupannya, sehingga mampu dengan dewasa menghadapi tantangan kemajuan zaman.

Sikap mandiri tentu bukan sesuatu yang dapat terjadi dengan tiba-tiba atau instan. Melainkan dengan pendidikan dan pelatihan serta pembiasaan.

Pendidikan merupakan sebuah proses pengubahan sikap dan tata laku seseorang atau kelompok orang dalam usaha mendewasakan manusia melalui upaya pengajaran dan pelatihan (W.J.S.Poerwadarminta:1966). Melalui pendidikan seseorang diproses menjadi dewasa, belajar sopan santun dan mengambil keputusan atau tindakan sendiri. Tujuan khusus pendidikan adalah terbentuknya kemampuan yang diharapkan melalui kegiatan pendidikan dan tujuan pendidikan secara umum yaitu terbentuknya manusia dewasa (Soegeng Santoso:2012). Manusia dewasa yang dimaksud adalah seseorang yang dapat mengambil dan mempertanggungjawabkan keputusannya.

Waktu yang tepat untuk mendidik anak memiliki kemandirian adalah usia dini. Usia 0-6 tahun di mana anak akan dengan cepat mempelajari segala sesuatu yang ada di sekitarnya. Belajar dan menyerap apa yang diajarkan orang dewasa di sekitarnya.

Anak usia dini sangat tertarik dengan dunia sekitarnya, rasa ingin tahunya sangat besar. Selain sering membongkar pasang segala sesuatu, anak juga gemar bertanya, suka berfantasi dan berimajinasi (Siti Aisyah,et.al:2014).

Kemandirian adalah sebuah sikap yang terbentuk karena dibiasakan. Tidak akan muncul dengan tiba-tiba. Seorang anak yang tidak dibiasakan mandiri, selalu dibantu dalam segala hal ketika dewasa akan mengalami kesulitan dalam membuat keputusan-keputusan, tidak mampu mengurus dan menolong diri sendiri.

Mandiri artinya memiliki kebebasan batin dalam mengenali pilihan-pilihan, mengambil pilihan-pilihan dan menanggung akibatnya, baik menyenangkan maupun menyakitkan (Robby I Chandra:2006).

Hasil observasi yang dilakukan di TK Kristen Kadasituru Terpadu, Desa Non Blok, Dusun Taripa, Kecamatan Kalaena, Kabupaten Luwu Timur, Provinsi Sulawesi Selatan menunjukkan bahwa tingkat kemandirian siswa masih rendah.

Ditemukan fakta bahwa dari 23 siswa TK Kelompok B, terdapat 17 anak yang sangat tergantung pada orang tua atau orang dewasa lainnya. Terlihat anak sering meminta 
bantuan membuka dan memakai sepatunya kembali, membuka dan merapikan peralatan makan saat kegiatan makan, merapikan mainan dan mengerjakan tugas.

Anak masih memiliki ketergantungan yang cukup besar terhadap orang dewasa, baik orang tua, pengasuh atau guru.

Sebagai langkah menolong meningkatkan kemandirian belajar anak didik, maka guru TK Kadasituru menerapkan teknik Scaffolding yaitu pembelajaran secara bertahap.

Auliya Astuti dalam karya tulis ilmiahnya mengatakan Scaffolding merupakan suatu pembelajaran dan siswa diberi sejumlah bantuan selama tahap-tahap awal pembelajaran, kemudian mengurangi bantuan tersebut sampai mampu mengerjakannya sendiri (Auliya Astuti:2017).

Menurut Shahabuddin Hashim Scaffolding merupakan bantuan yang diberikan kepada siswa supaya dapat menyiapkan tugas yang gagal disiapkan sendiri atau membantu siswa bergerak bebas sesuai perkembangan dengan membiarkan siswa menyelesaikan tugas tanpa bantuan orang lain (Shahabuddin Hashim:2007).

Permasalahan dalam penelitian ini dirumuskan sebagai berikut: pertama, bagaimana gambaran tingkat kemandirian anak TK Kadasituru Terpadu usia 5-6 tahun? Kedua, bagaimana penerapan teknik
Scaffolding sebagai upaya meningkatkan kemandirian belajar anak usia 5-6 tahun di TK Kristen Kadasituru Terpadu? Ketiga, Bagaimana hasil penerapan teknik Scaffolding dalam upaya meningkatkan kemandirian belajar anak usia 5-6 tahun di TK Kristen Kadasituru Terpadu?

Tujuan penelitian ini, pertama mendeskripsikan kemandirian belajar anak TK Kadasituru Terpadu usia 5-6 tahun. Kedua, mendeskripsikan penerapan teknik Scaffolding sebagai upaya peningkatan kemandirian belajar anak TK Kadasituru. Ketiga, mendeskripsikan hasil penerapan teknik Scaffolding dalam upaya meningkatkan kemandirian belajar anak TK Kadasituru.

\section{TINJAUAN PUSTAKA}

Sebagai dasar penelitian,berikut tinjauan beberapa teori yang berkaitan dengan dengan objek penelitian yaitu teknik scaffolding, tingkat kemandirian belajar, dan anak usia 5-6 tahun.

\section{TEKNIK SCAFFOLDING}

Teknik Scaffolding sering dilakukan atau diterapkan dalam suatu pendidikan, baik dalam meningkatkan kemampuan belajar anak maupun dalam pembiasan sehari-hari.

Suranto mendefinisikan Scaffolding sebagai berikut, "Scaffolding adalah pembelajaran yang menekankan kepada siswa 
mengambil makin banyak tanggung jawab untuk pembelajaran mereka sendiri."

Menurut Suranto dalam pembelajaran Scaffolding guru memberi contoh atau bantuan awal pembelajaran, kemudian secara bertahap mengalihkan tanggung jawab tersebut kepada siswa untuk melakukan sendiri.

Berbeda dengan Suranto, Kadek Adi Wibawa dalam tulisannya menyebut Scaffolding sebagai membangun dan menumbuhkan. $^{2}$ Artinya dalam proses pembelajaran yang terjadi adalah guru membangkitkan minat belajar anak melalui bimbingan yang terarah.

Pembelajaran scaffolding menurut Esa Sulaeman adalah "Pembelajaran yang memudahkan siswa belajar hal-hal yang di luar kemampuannya."3 Caranya, guru memberikan bimbingan secara bertahap sehingga membuat siswa mudah mengerjakan tanggung jawabnya di luar kemampuan yang dimiliki.

Senada dengan pendapat di atas disampaikan oleh Firmina Angela Nai. "Scaffolding merupakan proses pengendalian elemen-elemen tugas yang berada di luar kapabilitas siswa sehingga dapat

${ }^{1}$ Suranto, Teori Belajar dan Pembelajaran Kontemporer (Yogyakarta:2015), hal. 57.

${ }^{2}$ Kadek Adi Wibawa, Defragmenting Struktur Berpikir Pseudo dalam MemecahkanMasalah Matematika (Yogyakarta:2016), hal. 7. ${ }^{3}$ Esa Sulaeman, Pengenalan Pedagogi (Malaysia:2004), hal. 40. memfokuskan perhatian pada karakter tugas yang tidak dapat dipahami dan dikuasai dengan cepat."4 Guru terlebih dahulu memahami kemampuan anak, sehingga pembelajaran yang diberikan, dapat memudahkan siswa menguasai tugas dan tanggung jawabnya dengan cepat.

Trianto memberikan pengertian, "Scaffolding adalah memberikan sejumlah besar bantuan kepada anak selama tahap-tahap awal pembelajaran kemudian anak tersebut mengambil alih tanggung jawab yang besar setelah dapat melakukannya. ${ }^{5}$ Pada awal pembelajaran guru memberi bantuan dalam porsi besar, kemudian secara bertahap anak mengambil alih tanggung jawab tersebut.

Berikutnya menurut Baharuddin dan Esa Nur Wahyuni, "Scaffolding adalah memberikan dukungan dan bantuan kepada anak pada awal belajar, kemudian sedikit demi sedikit mengurangi dukungan atau bantuan setelah anak mampu memecahkan problem

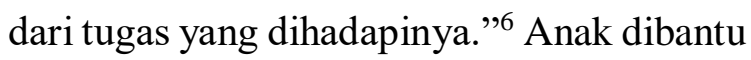
untuk memecahkan masalah yang dihadapi dengan cara guru atau orang dewasa memberi motivasi atau pujian terus-menerus hingga dapat menyelesaikan masalah yang dihadapinya sendiri.
${ }^{4}$ Firmina Angela Nai, Teori Belajar \& Pembelajaran Implementasinya DalamPembelajaran Bahasa Indonesia (Yogyakarta:2017), hal. 92.

${ }^{5}$ Trianto, Model Pembelajaran Terpadu Dalam Teori dan Praktik (Jakarta:2007), hal. 127.

${ }^{6}$ Buharuddin dan Esa Nur Wahyuni, Teori Belajar dan Pembelajaran (Jogjakarta:AR-RUZZ MEDIA,2007), hal. 30. 
Dari semua pendapat para ahli di atas dapat ditarik kesimpulan bahwa dalam teknik scaffolding terdapat langkah dari orang dewasa (guru, orang tua, pengasuh) mengajarkan sesuatu secara bertahap menurut kemampuan masing-masing anak. Kemudian setelah anak mampu melakukan, bantuan tersebut secara berangsur-angsur dikurangi. Tujuannya agar anak mengambil tanggung jawab lebih banyak dan besar untuk menyelesaikan tugasnya sendiri. Motivasi berupa dukungan dan pujian sangat penting dalam proses ini.

Karakteristik teknik scaffolding. Menurut pendapat Pol. Volman dan Beishuizen ada tiga yaitu contingency, fading dan transfer of responsibility. ${ }^{7}$ Contingency adalah: kemampuan yang bereaksi, dikhususkan, disesuaikan dan dibedakan. Dukungan yang diberikan guru harus disesuaikan dengan tingkat kemampuan siswa. Fading yaitu mengurangi bantuan yang telah diberikan. Tingkat pengurangan bantuan tergantung pada kompetensi dan perkembangan siswa. Transfer of responsibility merupakan pengalihan tanggung jawab tugas secara bertahap kepada siswa. Tugas yang diberikan kepada siswa terus meningkat, dari tingkat mudah sampai susah.

${ }^{7}$ Pol. Volman dan Beishuizen, Melatih Kemampuan Problem Posing (Jawa Barat:KDT Samedang Press,2018), hal. 86.

${ }^{8}$ Mckenzie, Model Pembelajaran Matematik (Jawa Barat:2016), hal. 87.
Mckenzy $^{8}$ memberikan pendapat tentang karakteristik scaffolding sebagai berikut: Menyediakan arah yang jelas dan mengurangi keraguan siswa. Guru harus menjelaskan dengan jelas untuk mencapai tujuan pembelajaran. Menjelaskan tujuan supaya murid tahu apa yang menjadi alasan melakukan hal tersebut. Menyediakan struktur, jalur atau langkah bagi siswa. Supaya siswa dapat mengambil keputusan sehingga tujuan pembelajaran (indikator) tercapai. Melakukan penilaian dan umpan balik dalam rangka mengklarifikasi tujuan dari tugas siswa. Mengarahkan siswa untuk memilih sumber belajar yang layak. Guru menawarkan beberapa sumber belajar kepada siswa dan siswa memilih sendiri. Membuang perasaan ragu-ragu. Guru mengarahkan siswa untuk mengantisipasi masalah yang dapat muncul.

Berikutnya adalah prinsip-prinsip pengajaran teknik Scaffolding. ${ }^{9}$ Pertama, membangkitkan rasa ingin tahu anak. Guru harus kreatif memperbesar rasa ingin tahu anak. Kedua, melibatkan peserta didik. Guru mengkondisikan anak terlibat dalam kegiatan dengan pembelajaran inkuiri. Rasa ingin tahu anak direalisasikan dengan jalan melakukan sendiri. Ketiga, pembentangan

\footnotetext{
${ }^{9}$ Mohd Zuri Ghani dan Aznan Che Ahmad, Kaidah dan Strategi Pengajaran KanakkanakBerkeperluan Khas (Malaysia:Universitas Sains,2011), hal 51.
} 
hasil kerja. Semua siswa menunjukkan hasil kerjanya dan diadakan tanya jawab, sehingga terjadi suasana pembelajaran interaktif yang ceria dan berkesan. Keempat, penilaian. Guru memastikan anak menangkap pembelajaran dengan bertanya jawab. Sehingga akan terlihat seberapa tingkat pemahaman siswa.

Prinsip-prinsip pembelajaran teknik Scaffolding menurut Isrok'atun "Prinsipprinsip scaffolding adalah pembelajaran yang terarah, berpusat pada murid, pembelajaran yang aktif dan motivasi." 10

Ruang lingkup pembelajaran dengan teknik Scaffolding menurut Ghani dan Aznan adalah Membagikan suatu tugas ke dalam sub-sub paling kecil, menyelesaikan tugas melalui pemikiran secara verbal, menerapkan pembelajaran bersama, melakukan kerja secara berkelompok, berani berdialog dan tanya jawab, menggunakan peraturan-peraturan isyarat dan memberi panduan tentang strategi dalam proses pengajaran dan pembelajaran. ${ }^{11}$

Berikut tentang langkah-langkah pembelajaran dengan teknik Scaffolding. Menurut Shahabuddin Hashim, langkahlangkah pembelajaran scaffolding adalah: Pertama, guru memberi bantuan kepada pelajar yang memerlukan untuk

${ }^{10}$ Isrok'atun, Psikologi Pendidikan Berbasis Analisis Empiris Aplikatif (Jawa Barat:2016), hal. 89. Op.Cit., hal 51. menyelesaikan tugasnya. Caranya, guru mendemonstrasikan sambil menjelaskan (modelling). Kemudian, guru meringkaskan atau membagikan suatu tugas dalam langkah yang mudah dipahami oleh siswa, guru menyediakan bantuan kepada siswa yang mengalami kesulitan dalam membuat tugas. Terakhir, guru berhenti memberi bantuan apabila siswa telah mampu menyelesaikan tugasnya. ${ }^{12}$

Setiap teknik pembelajaran ada kekurangan dan kelebihannya. Adapun kelebihan teknik pembelajaran Scaffolding menurut Shahabuddin Hashim: pertama, guru bertindak sebagai mentor dalam membimbing siswanya. Kedua, memperbolehkan siswa mengambil bagian dan menumpukan perhatian dalam pengajaran dan pembelajaran di kelas. Ketiga, memotivasi siswa untuk memberi perhatian lebih supaya inti pembelajaran dan jawaban yang diberikan guru dapat memberi manfaat kepada siswa dan akhirnya siswa mampu menyelesaikam tugas yang sulit dengan sendiri tanpa bantuan guru. Keempat, memotivasi siswa untuk berpikir mencari solusi permasalahan yang ditemui sebelum meminta bantuan kepada guru.

Menurut Pol. Volman dan Beishuizen kelebihan pembelajaran scaffolding antara

\footnotetext{
${ }^{12}$ Shahabuddin Hashim, et. al., Strategi dan Teknik Mengajar dengan Berkesan (Pulau Pinang:2007), hal 15.
} 
lain: kegiatan pembelajaran menjadi lebih bermakna karena siswa terlibat aktif dalam proses. Siswa menjadi lebih mandiri karena didorong untuk menemukan solusi dari masalah yang dihadapi dengan demikian pengetahuannya bertambah. Meminimalisir kebingungan siswa terhadap tugas yang diberikan, karena guru mendemonstrasikan dan menjelaskan. Siswa menjadi termotivasi untuk belajar dan mengerjakan tugas yang diberikan. $^{13}$

Kelemahan atau tantangan teknik ini adalah: guru memerlukan waktu yang lama untuk menyampaikan proses pengajaran. Guru yang diberi tanggung jawab untuk mengajar menggunakan pengajaran scaffolding tidak terlatih dalam mata pelajaran tertentu (materi pembelajaran), membuat siswa terlalu bergatung pada bantuan guru untuk menyelesaikan suatu tugas yang diberikan. ${ }^{14}$

Kesimpulan untuk hal tersebut adalah guru harus betul-betul paham materi pembelajaran yang akan diajarkan kepada siswa, supaya mengerti tugas yang dipelajari sehingga tidak selalu bertanya kepada guru atau bergantung penuh pada bantuan guru.

\section{KEMANDIRIAN BELAJAR.}

Kemandirian menunjukkan adanya kepercayaan akan kemampuan diri untuk menyelesaikan masalahnya tanpa bantuan 88.

\footnotetext{
${ }^{13}$ Pol. Volman dan Beishuizen, Op.Cit., hal.
}

$$
{ }^{14} \text { Ibid. }
$$

khusus dari orang lain. Mandiri identik selalu dapat memecahkan masalah sendiri tanpa bantuan orang lain. Sebagaimana kreativitas, kemandirian juga tidak bisa muncul begitu saja. Perilaku mandiri perlu dilatih sejak dini.

Beberapa definisi tentang kemandirian. Nugraha memberi definisi: Kemandirian dari kata dasar "Mandiri artinya keadaan dapat berdiri sendiri; tidak bergantung pada orang lain." "Kemandirian adalah keadaan dapat berdiri sendiri tanpa bergantung pada orang lain." ${ }^{15}$ Senada dengan hal di atas, Eti Nurhayati menyatakan: "Kemandirian adalah keinginan untuk mengerjakan segala sesuatu bagi diri sendiri." 16

Kemandirian menunjuk pada kemampuan psiko sosial yang mencakup kebebasan untuk bertindak, tidak bergantung kepada orang lain, tidak terpengaruh lingkungan dan bebas mengatur kebutuhan sendiri.

Kemandirian berarti kebebasan untuk mengambil inisiatif, mengatasi hambatan, melakukan sesuatu dengan tepat, gigih dalam usaha dan melakukan sendiri segala sesuatu tanpa bantuan orang lain.

Senada dengan tulisan di atas pendapat Lanny Octavia dkk, "Kemandirian adalah

${ }^{15} \mathrm{G}$. Setya Nugraha, Kamus Bahasa Indonesia Praktis (Surabaya:2013), hal 398.

${ }^{16}$ Eti Nurhayati, Psikologi Pendidikan Inovasi (Yogyakarta:2011), hal. 133. 
kesiapan dan kemampuan individu untuk berdiri sendiri yang ditandai dengan keberanian mengambil inisiatif, mencoba mengatasi masalah tanpa minta bantuan orang lain."17 Kemandirian merupakan perilaku seseorang untuk hidup dengan usaha sendiri tidak bergantung pada orang lain dan bertanggung jawab atas tugas sendiri. Oleh Hembing dalam buku Agus Sutoyo, hal ini disebutnya sebagai sikap hidup. Kemandirian adalah sebuah sikap hidup. ${ }^{18}$

Berkaitan dalam hal belajar, Andri dan Ahmad memberikan definisi, "Kemandirian adalah kemampuan untuk bertanggung jawab atas proses belajar untuk diri sendiri." 19

Kesimpulan dari semua definisi tentang kemandirian di atas adalah mandiri atau kemandirian adalah sebuah sikap hidup yang memutuskan untuk berinisiatif melakukan segala sesuatu secara bertanggung jawab tanpa menggantungkan diri pada bantuan orang lain terus-menerus.

Kemandirian belajar tidak sama dengan autodidak. Autodidak adalah orang yang tanpa bantuan guru bisa mendapat banyak pengetahuan dan dasar empiris yang besar dalam bidang tertentu. ${ }^{20}$ Kemandirian belajar bukan berarti belajar seorang diri, tetapi belajar dengan inisiatif sendiri tanpa bantuan orang lain yang relevan untuk membuat keputusan penting dalam menemukan kebutuhan belajarnya. Siswa memiliki kemampuan menentukan kapan membutuhkan bantuan dan kapan tidak dari orang lain saat belajar.

Kemandirian belajar menurut definisi beberapa ahli. Eti Nurhayati, "Kemandirian belajar merupakan bentuk belajar yang memberikan kesempatan kepada siswa untuk menentukan tujuan, sumber dan kegiatan belajar sesuai dengan kebutuhan sendiri."21 Dua pendapat yang senada dinyatakan oleh Wedmeyer dan Andri \& Ahmad. Wedmeyer mengatakan: "Kemandirian belajar adalah cara belajar yang memberikan kebebasan, tanggung jawab dan kewenangan yang lebih besar kepada siswa dalam merencanakan, melaksanakan dan mengevaluasi kegiatan belajar."22 Andri dan Ahmad menyatakan, "Kemandirian belajar merupakan sebuah kesiapan untuk bertanggung jawab

\footnotetext{
${ }^{19}$ Andri Wicaksono dan Ahmad Subhan Roza, Teori Pembelajaran Bahasa (Yogyakarta:Garudhawaca, 2016), hal 211.

${ }^{20}$ G. Setya Nugraha, Op.Cit., hal. 51.

${ }^{21}$ Eti Nurhayati, Op.Cit., hal. 141-142.

${ }^{22}$ Ibid.
} 
seseorang untuk melayani kebutuhan dan tujuan yang ingin dicapainya. ${ }^{23}$

Kesimpulan dari semua pendapat di atas tentang kemandirian belajar adalah cara belajar siswa dengan mengambil banyak kebebasan untuk merencanakan, melaksanakan dan mengevaluasi pekerjaan atau tanggung jawabnya dalam mencapai tujuannya. Siswa lebih otonom.

Cara-cara meningkatkan kemandirian belajar pada siswa pada prinsipnya dengan memberikan kesempatan untuk terlibat dalam berbagai aktivitas. Semakin banyak dilibatkan, semakin terampil dan terbiasa melakukan segala sesuatu dengan sendiri.

Anak-anak didorong agar mau melakukan sendiri kegiatan sehari-hari. Diberi kesempatan sesekali mengambil keputusan sendiri. Diberi kesempatan untuk bermain sendiri, sehingga terlatih untuk mengembangkan ide dan berpikir. Biarkan anak mengerjakan segala sesuatu sendiri, walaupun sering membuat kesalahan. Ketika bermain bersama, bermainlah sesuai keinginan anak. ${ }^{24}$

Kesimpulan: sekalipun anak atau siswa diberikan kebebasan untuk melakukan sendiri, mengingat usianya, orang dewasa yang ada di sekitarnya harus tetap

${ }^{23}$ Andri Wicaksono dan Ahmad Subhan Roza, Op.Cit., hal. 211.

${ }^{24}$ Tim Pustaka Familia, Membuat Prioritas, Melatih Anak Mandiri (Yogyakarta:2006), hal.49. mengawasi dan mengarahkan anak, supaya memahami apa yang baik dan tidak baik serta yang benar dan tidak benar untuk dilakukan.

\section{USIA DINI (Anak usia 5-6 tahun).}

Masnipal mengutip pendapat Maria Montessori menyebutkan bahwa, "Anak adalah pribadi yang unik dan bukan merupakan miniatur orang tua atau seperti benda kosong yang diisi sesuatu." ${ }^{25}$ Anak memerlukan bantuan orang dewasa untuk belajar banyak hal dalam hidupnya dan dapat mandiri.

Sesuai subjek penelitian maka yang menjadi fokus bahasan aspek perkembangan adalah anak usia 5-6. Pada usia ini cenderung sudah siap mengembangkan kemampuannya untuk bersekolah. Kemampuan berbahasanya lebih kompleks. Mampu berkomunikasi, mengeluarkan pendapat sendiri dan diajak berbagi cerita.

Perkembangan dari sisi fisik motorik, anak usia 5-6 tahun menurut Hurlock: anak belajar melompat dan berlari cepat, lompat tali, keseimbangan tubuh dalam berjalan di atas dinding atau pagar, sepatu roda, bermain sepatu es dan menari. ${ }^{26}$

Dari segi perkembangan spiritual, anak usia 5-6 tahun sudah dapat membedakan

${ }^{25}$ Masnipal, Siap Menjadi Guru dan Pengelola PAUD Profesional (Jakarta:2013), hal. 41.

${ }^{26}$ Elizabeth B. Hurlock, Psikologi Perkembangan (rev.ed;Jakarta), hal. 112. 
mana yang baik dan tidak baik. Secara nyata tentang agama, anak dapat diajari tentang Allah yang pengasih, doa, dan nyanyian rohani kristen yang dikaitkan dengan kehidupan sehari-hari. $^{27}$

Dari segi perkembangan kognitif, anak masuk fase praoperasional. Anak mulai menyadari bahwa pemahamannya tentang benda-benda di sekitarnya tidak hanya dapat dilakukan melalui kegiatan sensorimotor, akan tetapi juga dapat dilakukan melalui kegiatan yang bersifat simbolis. Jadi, anak sudah dapat berpikir menggunakan simbolsimbol.

Dalam segi kemampuan bahasa, anak usia 5-6 tahun sudah menguasai 800014.000 kosa kata. Lebih banyak menggunakan kata tanya untuk memuaskan rasa ingin tahunya.

Perkembangan sosio-emosional anak usia 5-6. Secara sosial anak senang bermain bersama dan tolong-menolong untuk mencapai sesuatu. Anak sudah mampu berbagi dengan orang lain, lebih sabar. Kemampuan emosi juga meningkat. Anak mampu mengekspresikan emosinya dengan mempelajari ekspresi orang lain.

Kesimpulan karakteristik anak usia 5-6 tahun (anak usia dini) adalah: Unik, egosentris, aktif dan energik, rasa ingin tahu kuat dan antusias, eksploratif dan berjiwa petualang, relatif spontan, kaya dengan fantasi, mudah frustasi, masih kurang pertimbangan dalam melakukan sesuatu, memiliki daya perhatian yang pendek, bergairah untuk belajar dan banyak belajar dari pengalaman, dan menunjukkan minat terhadap teman.

\section{METODE PENELITIAN}

Penelitian yang digunakan adalah Penelitian Tindakan Kelas atau PTK. Penelitian Tindakan Kelas adalah suatu kegiatan yang dilakukan oleh guru di kelasnya sendiri dengan merancang, melaksanakan, mengamati dan merefleksikan tindakan melalui beberapa siklus secara kolaboratif dan partisipatif yang bertujuan untuk memerbaiki atau meningkatkan mutu proses pembelajaran di kelas. ${ }^{28}$ Penelitian tindakan kelas merupakan terjemahan dari Classroom Action Research yaitu satu Action Research yang dilakukan guru di kelas. ${ }^{29}$ Menurut Samuel S. Lusi dan Ricky Arnold Nggili penelitian tindakan kelas merupakan suatu pencermatan terhadap kegiatan belajar, berupa sebuah

\footnotetext{
${ }^{28}$ Kunandar, Langkah Mudah Penelitian Tindakan Kelas Sebagai Pengembangan ProfesiGuru (Jakarta:2013), hal. 46.

${ }^{29}$ IGAK Wardhani, Kuswaya Wihardit, Penelitian Tindakan Kelas (Tangerang Selatan:Universitas Terbuka,2012), I, hal. 1.3.
} 
tindakan yang secara sengaja diadakan dan terjadi dalam sebuah kelas secara bersama. ${ }^{30}$

Penelitian tindakan kelas juga diartikan sebagai penelitian yang berorientasi pada tindakan dengan tujuan peningkatan mutu atau pemecahan masalah pada kelompok subjek yang diteliti dan mengamati tingkat keberhasilan atau akibat tindakannya untuk kemudian diberikan tindakan lanjutan yang bersifat penyempurnaan atau penyesuaian dengan kondisi dan situasi sehingga diperoleh hasil yang lebih baik. ${ }^{31}$

Kesimpulan: penelitian tindakan kelas adalah suatu kegiatan yang dilakukan oleh guru dengan sengaja di kelasnya sendiri dengan merancang, melaksanakan, mengamati dan merefleksikan tindakan yang bertujuan untuk meningkatkan mutu proses pembelajaran dan guru terlibat langsung dalam proses awal pembelajaran hingga selesai.

Model PTK yang digunakan adalah model Kurt Lewin. Empat tahapan yang dijalankan: perencanaan, pelaksanaan, pengamatan dan refleksi. ${ }^{32}$ Empat langkah ini dapat digambarkan seperti berikut:

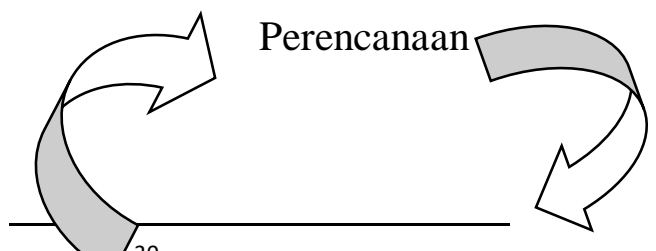

${ }^{30}$ Samuel S. Lusi dan Ricky Arnold Nggili, Asyiknya Penelitian Ilmiah dan PenelitianTindakan Kelas (Yogyakarta:ANDI,2013), hal, 56,58.

${ }^{31}$ Rocgiati Wiriaatmadja, Metode Penelitian Tindakan Kelas (Bandung:2007), hal.11.

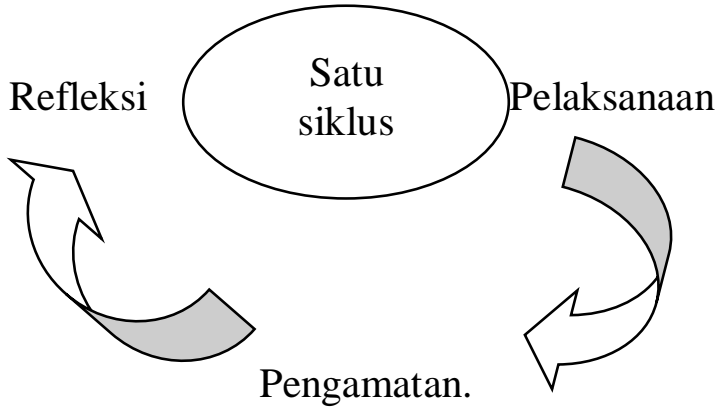

Penelitian dilaksanakan di TK Kristen Kadasituru Terpadu Desa Non Blok, Dusun Taripa, Kecamatan Kalaena, Kabupaten Luwu Timur, Provinsi Sulawesi Selatan. Dengan tujuan untuk meningkatkan kemandirian belajar anak karena belum terlihat atau rendah. Penelitian dilaksanakan dari Januari sampai Pebruari 2018.

Subjek penelitian adalah anak-anak kelompok B di TK Kristen Kadasituru Terpadu yang berjumlah 17 anak yang terdiri atas delapan anak laki-laki dan sembilan anak perempuan yang ditangani oleh satu orang guru kelas.

Dalam Penelitian Tindakan Kelas model Kurt Lewin dalam satu siklus terdapat empat langkah yaitu: Perencanaan, Pelaksanaan, Pengamatan, dan Refleksi.

Perencanaan mencakup tindakan yang akan dilakukan untuk memerbaiki, meningkatkan, atau merubah perilaku dan sikap yang

${ }^{32}$ Paizaluddin, Ermalinda, Penelitian Tindakan Kelas Panduan Teoritis dan Praktis (Bandung:Alfa Beta,2014), hal. 30. 
diinginkan sebagai solusi permasalahanpermasalahan. Perencanaan bersifat fleksibel, bisa berubah sesuai kondisi nyata yang ada. ${ }^{33}$ Dalam perencanaan peneliti merencanakan atau merancang kegiatan yang akan dilakukan. Seperti membuat $\mathrm{RPPH}$, lembar observasi dan alat peraga atau bahan kreatifitas untuk mengajar.

Tindakan merupakan realisasi dari suatu tindakan yang sudah direncanakan sebelumnya. ${ }^{34}$ Tindakan "Menyangkut apa yang dilakukan peneliti sebagai upaya pada rencana tindakan." ${ }^{35}$ Tindakan yang dimaksud dalam penelitian ini merupakan pelaksakaan dari rancana program pembelajaran harian (RPPH) menggunakan teknik pembelajaran bertahap, sebagai upaya meningkatkan kemandirian belajar anak. Proses penelitian tindakan kelas diadakan sebanyak empat Siklus, dengan rincian pelaksanaan sebagai berikut: Pelaksanaan siklus I sampai siklus IV, peneliti menerapkan langkah-langkah pembelajaran bertahap (scaffolding) model yang kedua menurut Shahabuddin Hashim yaitu: modelling, memberi penjelasan, tanya jawab, penyesuaian bahan pengajaran, sedia membantu dan memberi panduan. Siklus I dilaksanakan 15 Januari 2018, dengan tema

${ }^{33}$ Ekawarna, Penelitian Tindakan Kelas, (Jakarta:2013), hal. 21.

${ }^{34}$ Paizaluddin, Ermalinda, Op.Cit., hal 80.

${ }^{35}$ Ekawarna, Op.Cit., hal 21.
"Rekreasi”. Siklus II dilaksanakan 22 Januari 2018, dengan tema "Binatang" tentang meningkatkan kemandirian anak melalui penerapan teknik scaffolding. Siklus III dilaksanakan 29 Januari 2018, dengan tema "Rekreasi" tentang meningkatkan kemandirian anak melalui penerapan teknik scaffolding. Siklus IV dilaksanakan 05 Pebruari 2018, dengan tema "Pekerjaan" tentang meningkatkan kemandirian anak melalui penerapan teknik scaffolding.

Pengamatan dilakukan bersamaan dengan tindakan. Seperti yang dikatakan oleh Mohammad Asrori guru mengamati hasil atau dampak dari tindakan yang dilakukan. ${ }^{36}$ Pengamatan ini merupakan suatu tindakan yang dilakukan dalam mengamati proses pembelajaran penerapan teknik scaffolding oleh guru dan anak sebagai upaya meningkatkan kemandirian belajar anak usia 5-6 tahun.

Refleksi mengarah pada upaya individu atau kolektif untuk merenungkan apa yang sudah dicapai melalui tulisan atau cerita. ${ }^{37}$

Variabel penelitian. Penelitian "Penerapan Teknik Scaffolding Sebagai Upaya Meningkatkan Kemandirian Belajar Anak Usia 5-6 tahun di TK Kristen Kadasituru Terpadu" memiliki dua variabel

\footnotetext{
${ }^{36}$ Mohammad Asrori, Penelitian Tindakan Kelas (Bandung:2008), hal. 69

${ }^{37}$ Miftahul Huda, Penelitian Tindakan Kelas Teori dan Praktik (Yogyakarta:2015), hal.267.
} 
yaitu Teknik Scaffolding dan kemandirian belajar anak. Teknik Scaffolding ditetapkan sebagai variabel satu atau variabel $\mathrm{X}$ sedangkan kemandirian belajar anak adalah variabel kedua atau variabel Y. Hubungan kedua variabel tersebut dapat digambarkan:

\section{Variabel Penelitian}

\begin{tabular}{|l|l|c|}
\hline $\begin{array}{l}\text { Teknik } \\
\text { Scaffolding } \\
\text { Variabel X }\end{array}$ & $\begin{array}{c}\text { Kemandirian } \\
\text { Belajar Anak } \\
\text { Variabel Y }\end{array}$ \\
\hline
\end{tabular}

berikut: teknik Scaffolding, penetapan variabel $\mathrm{X}$ untuk mengetahui sejauh mana pengaruh dan efektifitas teknik Scaffolding terhadap kemandirian belajar anak usia 5-6 tahun di TK Kristen Kadasituru Terpadu. Selain itu, untuk mengetahui cara menerapkan teknik Scaffolding dalam proses pembelajaran sebagai upaya meningkatkan kemandirian belajar anak. Kemandirian belajar anak, kemandirian belajar anak sebagai variabel Y adalah untuk mengetahui kemandirian belajar anak sebelum dan setelah dilakukan penelitian serta untuk memahami apakah terjadi peningkatan sesuai harapan.

\section{METODE PENGUMPULAN DATA.}

Beberapa instrument yang digunakan untuk mengumpulkan adalah: observasi/ pengamatan. Menurut Widoyo, observasi merupakan alat pengumpulan data yang

\footnotetext{
${ }^{38}$ Eko Putro Widoyo, Teknik Penyusunan Instrumen Penelitian (Yogyakarta:2012), hal. 46-47. ${ }^{39} \mathrm{Ibid}$.
}

digunakan untuk mengamati perilaku manusia yang identik dengan data dalam bentuk catatan-catatan tertentu yang memengaruhi validitas data. ${ }^{38}$ Observasi merupakan salah satu metode pengumpulan data dan secara visual gejala diamati serta menginterpretasikan hasil pengamatan tersebut dalam bentuk catatan sehingga validitas data sangat tergantung pada kemampuan observasi. ${ }^{39}$

Dalam tahap pengamatan, peneliti berperan sebagai guru yang melakukan tugas mengajar atau melakukan tindakan. Sedangkan pengamat atau observer subjek penelitian yaitu Kepala Sekolah. Untuk melihat perkembangan kemandirian belajar masing-masing anak, peneliti bersama observer melakukan diskusi. Observasi menggunakan lembar chect list. Lembaran chectlist observasi terdapat skala.

Skala menurut Muhammad Asrori adalah seperangkat nilai angka yang ditetapkan kepada subjek yang digunakan untuk mengukur seberapa jauh seseorang memiliki ciri yang diteliti. ${ }^{40}$ Skala yang dipakai dalam penelitian ini adalah Skala Likert yaitu sejumlah pernyataan positif dan negatif mengenai suatu objek. ${ }^{41}$ Lembaran chect list observasi terdapat kriteria yang merupakan poin-poin indikator untuk mengukur

\footnotetext{
${ }^{40}$ Muhammad Asrori, Op.Cit., hal. 132.

${ }^{41}$ Ibid.
} 
seberapa jauh anak telah mencapai indikator kemandirian belajar yang diharapkan.

\section{Indikator Kemandirian belajar Anak}

\begin{tabular}{|l|l|}
\hline No. & Indikator \\
\hline 1. & $\begin{array}{l}\text { Anak mampu memasang dan membuka } \\
\text { sepatu sendiri. }\end{array}$ \\
\hline 2. & $\begin{array}{l}\text { Anak mampu merapikan sepatu pada } \\
\text { tempatnya. }\end{array}$ \\
\hline 3. & $\begin{array}{l}\text { Anak dapat mengerjakan tugas yang } \\
\text { diberikan guru sampai selesai. }\end{array}$ \\
\hline 4. & $\begin{array}{l}\text { Anak mengerjakan tugas sendiri tanpa } \\
\text { bantuan orang lain. }\end{array}$ \\
\hline 5. & $\begin{array}{l}\text { Anak dapat merapikan buku serta alat tulis } \\
\text { pada tempatnya. }\end{array}$ \\
\hline 6. & $\begin{array}{l}\text { Anak dapat merapikan mainan setelah } \\
\text { bermain pada tempatnya. }\end{array}$ \\
\hline 7. & $\begin{array}{l}\text { Anak mampu membuka dan merapikan } \\
\text { tempat makanannya sendiri. }\end{array}$ \\
\hline 8. & $\begin{array}{l}\text { Anak dapat membedakan perilaku yang } \\
\text { salah dan benar (minta maaf jika salah) }\end{array}$ \\
\hline
\end{tabular}

Presentase hasil observasi dihitung dengan rumus:

$$
P=\frac{F}{N} \quad X 100 \%
$$

Keterangan:

$\mathrm{P}=$ Persentase Pencapaian

$\mathrm{F}=$ Pencapaian Indikator

$\mathrm{N}$ = Jumlah Satuan/ Jumlah Indikator

$100 \%=$ Kriteria penilaian

Prosentase rata-rata dihitung dengan rumus:

$$
\begin{aligned}
& \mathrm{R} \\
& \mathrm{PR}= \\
& \mathrm{N}
\end{aligned}
$$

\footnotetext{
${ }^{42}$ Medi Yanto, Jadi Guru yang Jago Penelitian Tindakan Kelas (Yogyakarta:2013), hal.67.
}

\section{Keterangan:}

$\mathrm{PR}=$ Persentase Rata-rata

$\mathrm{R}$ = Nilai Rata-rata

$\mathrm{N}=$ Jumlah Penelitian/Jumlah anak

Hasil yang diperoleh kemudian dipresentasikan dalam empat kriteria penilaian:

\section{Kriteria Penilaian}

\begin{tabular}{|l|l|l|}
\hline No & Skor & Keterangan \\
\hline 1. & $1-25 \%$ & Belum Berkembang (BB) \\
\hline 2. & $26-50 \%$ & Mulai Berkembang (MB) \\
\hline 3. & $51-75 \%$ & $\begin{array}{l}\text { Berkembang } \\
\text { Harapan(BSH) }\end{array}$ \\
\hline 4. & $76-100 \%$ & Berkembang sangat Baik (BSB) \\
\hline
\end{tabular}

Tahap selanjutnya adalah menganalisa data. Analisa data merupakan bagian yang penting dalam penelitian. Pentingnya analisa data menurut Sukayati bahwa "Teknik analisis data merupakan lanjutan dari tahap analisa data. ${ }^{42}$ Analisa data diartikan sebagai cara melaksanakan analisis terhadap data dengan tujuan mengelola data tersebut untuk menjawab rumusan masalah. ${ }^{43}$ Dimulai dengan mengumpulkan data yang diperoleh dari pengamatan atau observasi yang sudah dituliskan dalam kegiatan pembelajaran,

${ }^{43}$ V. Wiratna Sujarweni, Metodologi Penelitian (Yogyakarta:2014), hal. 103. 
dengan demikian diperoleh informasi tentang kemandirian belajar anak.

Dalam Penelitian Tindakan Kelas (PTK) terdapat dua jenis data yang dapat dikumpulkan dan dianalisis yaitu kualitatif dan kuantitatif. ${ }^{44}$ Data kuantitatif dianalisis dengan menggunakan cara kuantitatif sederhana dengan persentase (\%), dan data kualitatif dianalisis dengan membuat penilaian-penilaian kualitatif (kategori). ${ }^{45}$ Data yang terkumpul pada setiap kegiatan adalah hasil observasi setiap Siklus dan akan dianalisa secara deskriptif kualitatif untuk menggambarkan kenyataan atau fakta sesuai data yang diperoleh untuk melihat sejauh mana teknik Scaffolding dapat meningkatkan kemandirian anak usia 5-6 tahun dan kuantitatif dengan menggunakan statistik deskriptif untuk mengetahui persentase kemandirian belajar anak berdasarkan kriteria/indikator yang telah disiapkan.

Analisis interaktif terdiri atas tiga komponen yaitu reduksi data, beberan (display) data dan penarikan kesimpulan. ${ }^{46}$ Reduksi data merupakan suatu proses menyeleksi, menentukan fokus, menyederhanakan, meringkas dan mengubah bentuk data mentah yang ada dalam catatan lapangan. ${ }^{47}$ Peneliti berdiskusi dengan supervisor (observer) untuk proses penyeleksian terhadap data yang sudah diperoleh selama proses pembelajaran berlangsung, mulai dari pembukaan, kegiatan sampai pada kegiatan penutup. Data yang sudah diperoleh selama proses belajar direduksi dengan memfokuskan pada upaya meningkatkan kemandirian belajar anak. Beberan (display) data, data yang diperoleh disajikan dengan menggunakan statistik deskriptif dengan rumus seperti tercantum di atas.

Langkah terakhir adalah penarikan kesimpulan. Dalam hal ini ditarik kesimpulan sementara pada akhir refleksi setiap siklus dan kesimpulan akhir pada analisis hasil penelitian. Agar hasilnya valid maka perlu diadakan trianggulasi data dengan membandingkan pendapat yang lain agar terhindar dari subjektivitas. Diskusi dengan supervisor, observer, dan pembimbing.

\section{HASIL DAN PEMBAHASAN}

Berdasarkan observasi pra peneliti selama tiga bulan proses pembelajaran efektif yakni sejak September sampai November sebelum dilakukan tindakan penelitian didapati kemandirian belajar anak sebagai berikut: Masuk kelas anak dibiasakan membuka, memasang dan merapikan sepatu sendiri. Faktanya R1, R2,

\footnotetext{
${ }^{44}$ Medi Yanto, Op.Cit., hal. 67

${ }^{45}$ Paizaluddin dan Ermalinda, Op.Cit., hal.
}

${ }^{46}$ Kunandar, Op.Cit., hal. 102.
${ }^{47}$ Ibid. 
R3, R4, R14, R11, R13, R15 dan R16 belum bisa membuka sepatu sendiri, selalu minta tolong dibukakan. R7, R12, R17, R10, R8, R6, R5 dan R9 sudah bisa membuka sepatu namun belum bisa memasang sendiri dengan tepat, sering meminta tolang kepada guru atau orang tuanya ketika datang menjemput terkadang memasang sepatu terbalik. R1, R2, R14, R3, R10, R17, R7, R12, R5, R9, R6, R11 dan R16 tidak pernah merapikan sepatunya pada tempatnya. Dalam proses belajar anak dibiasakan mengerjakan tugas yang diberikan oleh guru dengan mandiri sampai selesai, merapikan alat tulis pada tempatnya setelah digunakan dan merapikan mainan ketika selesai waktu bermain. Hasil observasi menunjukkan: R1, R2, R3, R4, R14, R11, R13, R15, R16, R7, R12, R17, R10, R8, R6, R5 dan R9 belum terbiasa mengerjakan tugas sendiri sampai selesai serta merapikan buku dan alat tulis pada tempatnya setelah digunakan. Masih dibimbing dan ditolong. R1, R4, R14, R3, R15, R16, R7, R12, R17, R6 dan R5 belum terbiasa merapikan mainan setelah bermain pada tempatnya. Pada saat istirahat, anak diajarkan membuka dan merapikan tempat makanannya, makan sendiri dengan rapi serta saling berbagi. R1, R2, R3, R4, R14, R11, R13, R15, R16, R7, R12, R17, R10, R8, R6, R5 dan R9 belum bisa membuka dan merapikan makanannya sendiri. Dalam hubungan sosial, anak-anak diajarkan untuk bermain bersama dan mengasihi (jika berbuat kesalahan saling meminta maaf dan memaafkan). R1, R2, R3, R4,R14, R11, R13, R15, R16, R7, R12, R17, R10, R6, R5 dan R9 belum terbiasa meminta dan memaafkan teman. Sedangkan R7, R12 dan R17 belum bisa diajak kerja sama atau bermain bersama (berbagi mainan). Dari keseluruhan indikator, rata-rata skor anak adalah 6,61\% masuk kategori Belum Berkembang (BB).

Deskripsi pelaksanaan tindakan dan hasilnya. Penelitian dilaksanakan JanuariFebuari 2018. Pelaksanaan Siklus I pada upaya meningkatkan kemandirian belajar anak usia 5-6 tahun melalui penerapan teknik Scaffolding dilaksanakan Senin, 15 Januari 2018 dengan tema Rekreasi dan sub tema Kendaraan. Proses penerapan scaffolding pada siklus I yaitu: pembelajaran berbaris di halaman sekolah dengan masih menggunakan sepatu. Kemudian anak diberi intruksi agar melepas sepatu sendiri dan meletakkannya di rak sepatu yang telah disiapkan. Jika anak kesulitan, diarahkan untuk minta bantuan kepada guru, tidak diizinkan meminta bantuan kepada orang tua. Guru memberi contoh meletakkan sepatu pada rak sepatu.Selama proses belajar siklus I penerapan scaffolding berupa pemberian motivasi agar anak didik berusaha mengerjakan tugas belajar sampai tuntas, mengerjakan sendiri tanpa bantuan orang lain. Memberikan arahan kepada anak didik 
dalam menggunakan dan menaruh kembali buku serta alat tulis pada rak yang telah disediakan. Demikian juga dalam penggunaan alat permainan edukatif. Guru memberi arahan dan motivasi agar anak membuka dan merapikan tempat makan tanpa minta bantuan. Guru menekankan agar setiap anak saling memaafkan, jika terjadi salah paham.

Observasi dilaksanakan bersamaan dengan pelaksanaan tindakan siklus. Kegiatan yang diamati berdasarkan indikator, mulai anak datang sampai pulang untuk melihat kemampuan anak memasang, membuka dan merapikan sepatu sendiri, melihat kemampuan anak mengerjakan tugas sendiri serta merapikan alat belajar pada tempatnya dan saat makan bekal, anak mampu membuka dan merapikan kembali tempat makan sendiri serta mau minta maaf dan memaafkan teman jika berbuat kesalahan. Dalam proses belajar mengajar selama satu hari sejak anak datang sampai pulang menerapkan langkah pembelajaran Scaffolding model kedua menurut Shahabuddin Hashim yaitu: modelling, memberi penjelasan, tanya jawab, penyesuaian bahan pengajaran, sedia membantu dan memberi panduan.

Hasil pengamatan menunjukkan: R7, R8, R9，R10，R14，R15，R16 dan R17 belum mampu memasang dan membuka sepatu sendiri masih dibantu guru. R4, R7, R8, R10,
R14, R15, R6, dan R17 belum terbiasa merapikan sepatu pada tempatnya. R1, R3, R4， R5， R6, dan R14 belum bisa mengerjakan tugas hingga selesai. R1, R2, R3, R4, R5, R6, R7, R9, R11, R13, R14, R15, R16, dan R17 belum dapat mengerjakan tugas sendiri, masih dengan pendampingan guru. R1, R2, R4, R5, R6, R7, R8, R9, R11, R13, R14, R15, R16, dan R17 belum terbiasa merapikan alat belajarnya sendiri pada tempatnya. R1, R2, R3, R4, R5, R6, R7, R8, R9, R10, R11, R12, R13, R14, R15, R16, dan R17 belum terbiasa merapikan mainan. R3, R4, R5, R6, R7, R8, R9, R10, R11, R12, R13, R14, R15, R16, dan R17 masih belum bisa atau terbiasa membuka dan merapikan tempat makanannya sendiri. R2, R4, R5, R6, R7, R8, R12, R14, R15, R16 belum dapat membedakan perilaku yang salah dan benar yaitu meminta maaf jika berbuat kesalahan. Hasil tindakan siklus I menunjukkan skor rata-rata $31,61 \%$ pada kategori Mulai Berkembang (MB).

Dari skor di atas dapat dikatakan pelaksanaan siklus I dapat dikatakan baik. Dari refleksi menunjukkan kemandirian belajar anak ada peningkatan, namun masih harus ditingkatkan lagi.

Dari refleksi didapati kendala-kendala. Observer orang baru bagi anak-anak sehingga pelaksanaan kurang tertib. Anak-anak mencari perhatian. Kendala lainnya, anak-anak belum 
dapat membedakan gambar dan menulis lambang bilangan sesuai jumlah gambar. Usia 5-6 tahun seharusnya dapat membedakan gambar dan menulis lambang bilangan sesuai jumlah gambar. Pada kegiatan selanjutnya, anak harus dijelaskan lebih detail dan harapan melalui pelaksanaan siklus selanjutnya kemandirian belajar anak bisa meningkat.

Analisa pelaksanaan siklus I, kemandirian belajar anak belum terlihat dengan capaian skor $31,61 \%$ memenuhi kriteria Mulai Berkembang (MB). Peningkatan kemandirian belajar anak mulai terlihat terutama pada anak yang mencapai skor tertinggi yaitu R12. Anak mampu menunjukkan kemandirian belajar dengan berusaha mengerjakan tugasnya sendiri, merapikan peralatan belajar, merapikan mainan, membuka dan merapikan tempat bekal, membuka dan memakai sepatu serta merapikan sepatu pada tempatnya. Satu anak tidak menunjukkan adanya peningkatan kemandirian belajar yaitu R14 meskipun peneliti telah berusaha menolong anak dengan memberikan motivasi dan arahan.

Pelaksanaan siklus II. Dilaksanakan Senin, 22 Januari 2018 dengan tema Rekreasi dan sub tema macam-macam Kendaraan. Proses penerapan teknik scaffolding pada siklus II dalam upaya meningkatkan kemandirian belajar anak yaitu: berbaris di halaman sekolah dengan masih menggunakan sepatu. Kemudian anak diberi instruksi agar melepas sepatu sendiri dan menaruhnya di rak yang telah disiapkan, jika anak kesulitan diarahkan untuk minta bantuan guru. Guru memberi contoh meletakkan sepatu pada rak sepatu. Selama proses belajar di siklus II penerapan scaffolding berupa pemberian motivasi agar anak didik berusaha mengerjakan tugas belajar sampai tuntas, mengerjakan sendiri tanpa bantuan orang lain, jika ada kesulitan guru siap membantu. Memberikan arahan kepada anak didik dalam menggunakan dan menaruh kembali buku serta alat tulis pada rak yang telah disediakan. Demikian juga dalam penggunaan alat permainan edukatif. Pada waktu makan bekal, guru memberi arahan serta motivasi agar anak membuka dan merapikan tempat makan tanpa minta bantuan. Guru menekankan agar anak saling memaafkan, jika melakukan kesalahan.

Siklus II sesuai dengan rencana dan hasil observasi menunjukkan kemandirian belajar anak mulai meningkat. Hasil observasi siklus II diperoleh skor rata-rata dari keseluruhan siswa yaitu 52,20\% mencapai kriteria Berkembang Sesuai Harapan (BSH). Satu anak masih pada kriteria Belum Berkembang (BB) yaitu R7. Tiga anak mencapai kriteria Mulai Berkembang (MB) yaitu: R2, R6 dan R16. 10 anak mencapai kriteria Berkembang Sesuai Harapan (BSH) yaitu R1, R4, R3, R5, R8, R9, R12, R14, R15 dan R17. Tiga orang mencapai kriteria 
Berkembang Sangat Baik (BSB) yaitu R10, R11 dan R13.

Refleksi dilakukan setelah pelaksanaan tindakan dan observasi. Sesuai pengamatan pelaksanaan siklus II sudah ada peningkatan kemandirian belajar pada anak. Hasil refleksi menjadi landasan bagi pelaksanaan siklus selanjutnya, khususnya setiap indikator yang belum muncul atau belum dicapai masing-masing anak.

Analisa siklus II. Penerapan teknik Scaffolding pada Siklus II cukup berhasil dalam meningkatkan kemandirian belajar anak dengan nilai rata-rata $63,23 \%$ memenuhi kriteria Berkembang Sesuai Harapan (BSH). Peningkatan tertinggi terlihat ketika anak mampu memotivasi diri demi tercapainya setiap indikator. Memasang dan membuka sepatu sendiri dicapai 14 anak. Merapikan sepatu pada tempatnya dan mengerjakan tugas sendiri tanpa bantuan orang lain dicapai 12 anak. Membuka dan merapikan tempat makanan dicapai 13 anak dan perkembangan kemandirian belajar yang baik juga dicapai oleh R14, semakin mampu memotivasi diri untuk mandiri atau bertanggung jawab.

Pelaksanaan Siklus III dilaksanakan Senin, 29 Januari 2018 dengan tema Rekreasi dan sub tempat-tempat rekreasi. Proses penerapan teknik scaffolding pada siklus III: berbaris di halaman sekolah masih mengenakan sepatu. Kemudian anak diberi intruksi agar melepas sepatu sendiri dan menaruhnya di rak sepatu yang telah disiapkan. Guru terus memberi contoh meletakkan sepatu pada rak sepatu. Dalam siklus III penerapan teknik Scaffolding berupa pemberian motivasi agar anak berusaha mengerjakan tugas belajar sampai tuntas, mengerjakan sendiri tanpa bantuan orang lain dan tugas yang disediakan guru terus meningkat berdasarkan kemampuan dan perkembangan anak. Setelah selesai anak menaruh kembali buku dan alat tulis pada rak, jika ada anak yang tidak bertanggung jawab atas buku dan alat tulisnya, guru sedia memberi motivasi serta arahan. Guru memberi arahan dan motivasi agar anak membuka dan merapikan tempat makan sendiri pada waktu makan bekal. Selama proses belajar, guru menekankan agar setiap anak saling memaafkan.

Hasil observasi siklus III menunjukkan bahwa kemandirian belajar anak terus meningkat. Pencapaian skor rata-rata meningkat menjadi $72,05 \%$ pada kriteria Berkembang Sesuai Harapan (BSH). Sembilan anak belum mencapai target yang diharapkan dari delapan indikator, ada lima indikator yang belum dicapai. Kesembilan anak: R1, R2, R6, R9 dan R14 masih belum terbiasa merapikan alat tulis pada tempatnya. R3, R7, R12 dan R16 masih dibimbing dalam mengerjakan tugas hingga selesai. R6, R9 dan R16 belum terbiasa 
merapikan mainan pada tempatnya. R13 belum mampu mengerjakan semua tugas yang diberikan hingga selesai dan $\mathrm{R} 7$ belum bisa membedakan perilaku yang salah dan benar (masih sulit minta maaf dan memaafkan).

Pada siklus III bisa dikatakan belum berhasil karena masih ada sembilan anak belum mencapai semua indikator. Kendalanya: tiga anak tidak masuk sekolah karena sakit, satu anak belum mampu menyelesaikan semua tugas karena memang lambat dalam mengerjakan tugas dan empat anak belum bisa mengerjakan tugas sendiri karena kurang mengerti dan teliti tidak memerhatikan ketika guru menjelaskan. Harapan pada pelaksanaan tindakan siklus terakhir semua indikator dapat tercapai dan peneliti harus mencari gaya belajar yang berbeda dari sebelumnya.

Ada perbedaan antara anak yang terbiasa bertanggung jawab atau mandiri dan tidak. Dengan penerapan teknik Scaffolding suasana pembelajaran menjadi lebih tertib. Juga dapat menolong dan saling mengingatkan untuk bertanggung jawab dan memecahkan masalah yang dihadapi. Ratarata pencapaian peningkatan kemandirian belajar menunjukkan nilai $72,05 \%$ memenuhi kriteria Berkembang Sesuai Harapan (BSH). Pencapaian perkembangan kemandirian belajar Meisya semakin meningkat dengan skor $87,5 \%$.
Pelaksanaan Siklus IV dilaksanakan Senin 5 Pebruari 2018 dengan tema Pekerjaan dan sub tema Macam-Macam Pekerjaan. Proses siklus IV: berbaris di halaman kelas dengan masih mengenakan sepatu. Kemudian anak diberi intruksi agar melepas sepatu sendiri dan menaruhnya di rak sepatu. Guru tidak lagi memberi contoh. Penerapan Scaffolding berupa pemberian motivasi agar anak berusaha mengerjakan tugas sampai tuntas, mengerjakan sendiri tanpa bantuan. Setelah selesai anak menaruh kembali buku dan alat tulis pada rak. Guru tidak memberi motivasi serta arahan. Pelaksanaan Siklus IV berdasarkan refleksi Siklus III. Pelaksanaan tindakan siklus IV model pembelajaran berbentuk kelompok, kegiatan yang dikerjakan berbeda. Dengan pembelajaran berkelompok, peningkatan kemandirian belajar anak sangat terlihat. Dari 17 anak subjek penelitian hanya dua orang yang belum mencapai semua indikator yaitu R4 dan R7. Pada pelaksanaan tindakan siklus IV skor rata-rata pencapaian anak secara keseluruhan terus meningkat menjadi 98,52\% mencapai kriteria Berkembang Sangat Baik (BSB).

Hasil refleksi siklus IV terlihat peningkatan kemandirian belajar anak, meskipun tidak semua dari 17 anak yang menjadi subjek, mencapai delapan indikator yang menjadi tolak ukur pencapaian kemandirian belajar anak. Indikator yang 
belum dapat dicapai adalah mengerjakan tugas sendiri tanpa bantuan karena memang membutuhkan bimbingan khusus. Kedua anak tersebut adalah R4 dan R7. Penerapan Siklus IV yang merupakan siklus terakhir mampu meningkatkan kemandirian belajar anak. Nilai rata-rata yang diperoleh adalah 98,52\% memenuhi kriteria Berkembang Sangat Baik (BSB). Penerapan teknik Scaffolding sebagai upaya meningkatkan kemandirian belajar anak dapat membangun rasa kepedulian, inisiatif dan tanggung jawab pada anak. Anak semakin terbiasa bertanggung jawab dan memecahkan masalah yang dihadapi.

\section{KESIMPULAN}

Dapat disimpulkan bahwa teknik
Scaffolding dapat meningkatkan kemandirian belajar anak usia 5-6 tahun di TK Kristen Kadasituru Terpadu, dibuktikan dari peningkatan pencapaian indikator oleh setiap anak pada pelaksanaan siklus. Teknik scaffolding ini juga dapat diterapkan di Taman Kanak-Kanak sebagai strategi proses belajar mengajar dalam hal meningkatkan kemandirian belajar anak. Dengan karakteristik pengajarannya adalah guru memberi bantuan sesuai tingkat kemampuan siswa, mengurangi bantuan sesuai perkembangan siswa, memberi tanggung jawab secara bertahap, menjelaskan pembelajaran dengan jelas, menjelaskan tujuan pembelajaran, menyediakan struktur, melakukan penilaian, siswa memilih sumber belajar sendiri, menghilangkan perasaan ragu-ragu.

Prinsip pengajarannya adalah meningkatkan rasa ingin tahu anak, penglibatan diri, pembentangan hasil kerja, melakukan penilaian, pembelajaran terarah, berpusat pada murid, pembelajaran yang aktif dan pemberian motivasi.

\section{DAFTAR PUSTAKA}

Ekawarna. 2013. Penelitian Tindakan Kelas. Jakarta: REFERENSI

Huda, Miftahul. 2015. Penelitian Tindakan Kelas Teori dan Praktik. Yogyakarta: PUSTAKA PELAJAR

Hurlock, Elizabeth B. 2011. Psikologi Perkembangan Suatu

PendekatanSepanjang Rentang

Kehidupan. Jakarta: Erlangga

IGAK, Wardhani dan Wihardit, Kuswaya. 2012. Penelitian Tindakan Kelas. Tangerang Selatan: Universitas Terbuka

Isrok'atun. 2016. Psikologi Pendidikan Berbasis Analisis Empiris Aplikatif. Jawa Barat: Universitas Sains Malaysia

Kunandar, 2013. Langkah Mudah Penelitian Tindakan Kelas SebagaiPengembangan Profesi Guru. Jakarta: RajaGrafindo Persada.

Lusi, Samuel S dan Nggili, Ricky Arnold. 2013. Asyiknya Penelitian Ilmiah danPenelitian Tindakan Kelas. Yogyakarta: ANDI

Masnipal. 2013. Siap Menjadi Guru dan Pengelola PAUD Profesional. Jakarta: Elex Media Komputindo

Mckenzie. 2016. Model Pembelajaran Matematik. Jawa Barat: KDT Samedang Press

Nai, Firmina Angela. 2017. Teori Belajar \& Pembelajaran Implementasinyadalam Pembelajaran Bahasa Indonesia. Yogyakarta: DEEPUBLISH 
Nurhayati, Eti. 2011. Psikologi Pendidikan Inovasi. Yogyakarta: Pustaka Pelajar

Paizaluddin dan Ermalinda. 2014. Penelitian Tindakan Kelas Panduan Teoritisdan Praktis. Bandung: Alfa Beta

Volman, Pol. dan Beishuizen. 2018. Melatih Kemampuan Problem Posing Jawa Barat: KDT Samedang Press

Wibawa, Kadek Adi. 2016. Defragmenting Struktur Berpikir Pseudo dalamMemecahkan Masalah Matematika. Yogyakarta: CV BUDI UTAMA

Wicaksono, Andri dan Roza, Ahmad Subhan. 2016. Teori Pembelajar Bahasa. Yokyakarta: Garudhawaca

Yanto, Medi. 2013. Jadi Guru yang Jago Penelitian Tindakan Kelas, Yogyakarta: ANDI

Auliya Astuti, Pengertian Pembelajaran Scafollding,http://karyatulisilmiah.com. Akses Internet 12 Juli 2017. 